\title{
ANALISIS SEMIOTIKA EKSPRESI WAJAH DI DALAM AYAT-AYAT AGUNG AL-QUR'AN
}

\author{
Hasanuddin Chaer*, Ahmad Sirulhaq**, Abdul Rasyad*** \\ *,**Universitas Mataram, $* * *$ Universitas Hamzanwadi \\ *hasan.unram@gmail.com \\ **ahmad_haq@unram.ac.id
}

\begin{abstract}
Semiotics is the study of signs and symbols as elements and analysis of communication systems. Many verses of the Qur'an show aspects of communication between bumans and verses of the Qur'an. This article discusses the study of semiotics with a descriptive analysis approach. The purpose of this essay is to analyze facial expressions in the verses of the Great Qur'an that are expressed verbally. This essay uses Peirce's theory of semiotics in analyzing the facial expressions of people in the world and the faces of people in the afterlife.
\end{abstract}

Keywords: Semiotics, Al-Qur'an, Facial Expressions

\begin{abstract}
Abstrak: Semiotika adalah studi tentang tanda dan simbol sebagai elemen dan analisis sistem komunikasi. Banyak ayat Al-Qur'an yang menunjukkan aspek komunikasi antara manusia dan ayat Al-Qur'an. Artikel ini membahas studi semiotika dengan pendekatan analisis deskriptif. Tujuan esai ini untuk menganalisis ekspresi wajah di dalam ayat-ayat Agung Al-Qur'an yang diekspresikan secara verbal. Esai ini menggunakan teori semiotika Peirce dalam menganalisis ekspresi wajah orang-orang di dunia dan wajah orang-orang di akhirat.
\end{abstract}

Kata Kunci: Semiotika, Al-Qur'an, Ekspresi Wajah

\section{PENDAHULUAN}

Dalam komunikasi manusia ada dua aspek penting yaitu komunikasi verbal dan nonverbal. Komunikasi verbal berkaitan dengan bahasa lisan untuk menyampaikan pesan. Sementara komunikasi nonverbal adalah proses mengkomunikasikan pesan melalui bahasa wajah, gerakan tubuh, nada suara, kontak mata dan sebagainya. Dengan demikian bahasa tubuh adalah salah satu cara yang paling berpengaruh dari perilaku visual nonverbal, 
termasuk ekspresi wajah dan sebagainya ${ }^{1}$. Ekspresi wajah menyiratkan pengungkapan berbagai emosi dan perilaku interpersonal yang mengungkapkan karakterisasi tertentu dari seseorang. Oleh karena itu, ekspresi wajah adalah aspek penting komunikasi nonverbal untuk komunikasi sosial, terutama untuk mereka yang memungkinkan mengekspresikan dan memahami emosi dan mental yang tak terucapkan ${ }^{2}$. Namun Izard $^{3}$ mengklasifikan ekspresi wajah menjadi emosi yang berbeda seperti ketakutan, jijik, kemarahan, kebahagiaan, kejutan, kesedihan dan netral. Perbedaan emosi dengan penggunaan ekspresi ini dapat diprediksi. Analisis ekspresi afektif manusia telah menarik perhatian dari para peneliti dibidang psikologi, linguistik, dan disiplin ilmu lainnya. Namun jarang kita menemukan para peneliti yang mengkaji studi ekspresi wajah pada tingkat analisis semiotik ${ }^{4}$. Dengan demikian, artikel ini bertujuan untuk menganalisis ekspresi wajah di dalam ayat-ayat agung Al-Qur'an dan untuk pengayaan kerangka teori kepustakaan AlQur'an dibidang semiotik. Oleh karena itu artikel ini membahas dua pertanyaan penelitian: pertama; apakah makna ekspresi wajah orang-orang di dunia dan wajah orang-orang di akhirat yang diungkapkan melalui ayat-ayat Agung Al-Qur'an. Kedua; bagaimanakah fungsi semiotika dalam ayat-ayat Al-Qur'an sebagai sarana komunikasi?

Artikel ini menggunakan teori semiotika Peirce. Berdasarkan "semiosis" hubungan antara tanda, objek, dan makna, tanda itu mewakili objek. Interpretant mengacu pada tanda yang berfungsi sebagai representasi dari suatu objek. Tanda dapat berupa (kata-kata) verbal atau non verbal ${ }^{5}$. Sementara semiotika menurut ${ }^{6}$, setiap orang adalah penafsir tanda. Tanda yang memandu seseorang dalam menginterpretasikan kata, gambar, dan juga gerakan tubuh yaitu dari segi aspek designative yang mengarahkan penerjemah kekajian makna semiotik ayat-ayat Al-Qur'an. Menurut Morris, tindakan manusia melibatkan tanda dan makna melalui persepsi yaitu orang menjadi sadar akan suatu tanda, menafsirkan dan

${ }^{1}$ Eisenberg, A. M. \& R. R. Smith, Nonverbal Communication, (New York: The Bobbs-Merrill Company, Inc., 1971), 213. Lihat juga Levine, D. R. \& M. B. Adelman, Beyond language: Intercultural Communication for English as a Second Language. Englewood Cliffs, (New York: Prentice-Hall, Inc., 1982), 234.

${ }^{2}$ Ekman, P., What the facereveals (2nd edition): Basic and applied studies of spontaneous Expression using the Facial Action Coding System (FACS), (2005), 388-392.

${ }^{3}$ Izard, C., The face of Emotion, (New York: Appleton-Century-Crofts, (1971), 119.

${ }^{4}$ Abdullah, A., et. al.,"The Semiotic Studies of the Holy Qur'an", QURANICA-International Journal of Quranic Research, Vol. 8 No. 1(2016), 91-108.(https://doi.org/10.22452/quranica.vol8no1.6.)

5Pierce, Sanders Charles.,State of Vermont V. Carroll B. Pierce. Supreme Court of Vermont, (Bennington, 1958), 167. ${ }^{6}$ Morris, Charles., "Charles Morris and the Behavioral Foundations of Semiotics. In: Krampen M., Oehler K., Posner R., Sebeok T.A.”, von Uexküll T. (eds),Classics of Semiotics. Topics in Contemporary Semiotics,(Boston: Springer, 1987), 23-57. 
menjelaskannya. Simbolisme yang mendasari pemahaman dan pengetahuan semua manusia. Simbol adalah alat untuk konsepsi objek. Simbol adalah “instrumen pemikiran” yang memungkinkan seseorang untuk memikirkan sesuatu selain dari kehadirannya yang segera ${ }^{7}$. Simbol menjadi bermakna dalam wacana Al-Qur'an. Simbol dapat bersifat diskursif atau non-diskursif. Simbolisme diskursif adalah pemikiran dan makna berbasis bahasa simbolisme. Simbolisme non-diskursif adalah emosi dan makna non-verbal seperti seni, musik, tarian dan gerakan tubuh lainnya. Makna dapat ditemukan dalam simbolisme nondiskursif dan diskursif. Setiap tanda memiliki banyak potensi makna. Beragam makna dipengaruhi secara sosial dan budaya. Tanda memiliki makna denotatif dan konotatif yang melibatkan kata-kata, emosi dalam menafsirkan makna gerakan tubuh seperti ekspresi wajah.

\section{METODE DAN PENDEKATAN PENELITIAN}

Artikel ini menggunakan metode analisis deskriptif. Kami menganalisis makna semiotika pada gerakan tubuh seperti ekspresi wajah yang ada di dalam ayat-ayat Al-Qur'an yang kami pilih. Metode ini menggunakan analisis semiotik tentang ekspresi wajah yang digunakan berkomunikasi di dalam ayat-ayat Agung Al-Qur'an yang harus memiliki perhatian khusus. Ayat-ayat Agung Al-Qur'an kami pilih dari berbagai bab (surah) untuk mencapai data yang memadai yang terkait dengan ekspresi wajah. Penulis meniliti 12 (bab) Surah Al-Qur'an yang terdiri dari 20 Ayat yaitu ; Bab 2, Al-Baqarah: 144, Bab 3, Al-Imran: 106-107, Bab 10, Yunus: 27, Bab 16, An-Nahl: 58-59, Bab 17, Al-Israa': 7, Bab 22, Al-Hajj: 72, Bab 39 ; Az-Zumar: 60, Bab 48, Al-Fath: 29, Bab 67, Al-Mulk: 22, Bab 75, Al-Qiyamah: 22,23,24, Bab 80, Abasa': 38, 39, 40,41, Bab 88, Al-Ghaasyiah: 2 dan 8. Kami mengadopsi teori semiotika Peirce, kami memilih ayat-ayat Al-Qur'an yang berbeda dengan berbagai bentuk bahasa dan kami analisis ayat-ayat Al-Qur'an yang secara verbal mencerminkan, menggambarkan dan menyatakan ekspresi wajah. Kami identifikasi ekspresi setiap wajah dalam komunikasi verbal ayat-ayat Al-Qur'an yang kami pilih dan klarifikasi konteks teks setiap item ayat melalui referensi langsung ke nama Surah (Bab) dari setiap ayat Al-Qur'an yang kami pilih dan jumlah ayat yang bersangkutan pada tafsir Al-Mukhtasor fi Tafsir Al-

${ }^{7}$ Ibid, 57. 
Qur'anil Karïm. At-tashniif: Jama'atin min Ulama'it tafsir $(1439 . \mathrm{H})^{8} \mathrm{dan}$ terjemahan AlQur'an cetakan kerajaan Saudi Arabia; Raja Fahd ibn'Abd al'Aziz Al Sa'ud (1990) ${ }^{9}$. Sumber data yaitu Ayat-ayat Al-Qur'an yang mencakup ekspresi wajah yang mengungkapkan berbagai emosi kesedihan, kebahagiaan, kemarahan, ketakutan, kebencian dan sebagainya. Ayat-ayat ini dapat diklasifikasi menjadi dua jenis ekspresi wajah yang kami amati yaitu ekspresi wajah orang-orang di akhirat dan ekspresi wajah orang-orang di dunia saat ini, kemudian kami analisis, tafsirkan dan menjelaskannya.

Penelitian tentang semiotika yang relevan dengan penelitian ini seperti yang telah diteliti oleh Suko Winarsih dengan judul penelitian "Representasi Bahasa dalam Pertarungan Simbolik dan Kekuasaan". Namun artikel ini membahas Representasi semiotika kebenaran melalui makna simbol yang universal dalam hubungannya dengan mekanisme sosial antara kekuatan dan pelecehan sosial ${ }^{10}$. Penelitian oleh Ery Agus Kurnianto di Balai Bahasa Provinsi Sumatera Selatan dengan judul penelitian "Analisis Tiga Tataran Aspek Semiotik Tzvetan Todorov Pada Cerpen "Pemintal Kegelapan” Karya Intan Paramaditha". Pada penelitian cerpen "Pemintal Kegelapan" ini membahas segi-segi struktur karya yaitu dari aspek sintaksis, aspek semantik dan aspek verbalnya ${ }^{11}$. Berbeda dengan penelitian ini yang meneliti tentang "Ekspresi Wajah dalam Ayat-Ayat Agung AlQur'an Analisis Semiotika”, yang terdapat di dalam 12 (bab) Surah Al-Qur'an yang terdiri dari 20 Ayat yaitu; Bab 2, Al-Baqarah: 144, Bab 3, Al-Imran: 106-107, Bab 10, Yunus: 27, Bab 16, An-Nahl: 58-59, Bab 17, Al-Israa': 7, Bab 22, Al-Hajj: 72, Bab 39 ; Az-Zumar: 60, Bab 48, Al-Fath: 29, Bab 67, Al-Mulk: 22, Bab 75, Al-Qiyamah: 22,23,24, Bab 80, Abasa': 38, 39, 40,41, Bab 88, Al-Ghaasyiah: 2 dan 8. Yaitu kami analisis ekspresi wajah orangorang yang bahagia dan bimbang di dunia ini dan di akhirat melalui makna semiotika ayatayat Al-Qur'an tersebut.

\footnotetext{
${ }^{8}$ Al-Mukhtasor, Al-Mukbtasor fi Tafsïril Qur'anil Karïm/Tashnip: Jama'atin min Ulama' it Tafsiir/Nukbbab minal ulama', Thob'ah 4, (Riyadh: Al-Markaz Liddirosaatil Qur'aniyyah, 1439 H).

${ }^{9}$ Kerajaan Saudi Arabia, Al-Qur'an,(Riyad: Raja Fahd ibn'Abd al'Aziz Al Sa'ud, 1990).

${ }^{10}$ Winarsih, Suko., "Representasi Bahasa dalam Pertarungan Simbolik dan Kekuasaan". Jurnal Bahasa Lingua Scientia,Vol. 5 No. 1 (2013), 11-24. (10.21274/1s.2013.5.1.11-24).

${ }^{11}$ Kurnianto, Ery Agus., "Analisis Tiga Tataran Aspek Semiotik Tzvetan Todorov Pada Cerpen "Pemintal Kegelapan” Karya Intan Paramaditha”, KANDAI, Vol. 11 No 2, (2015), 206-216. (https://doi.org/10.26499/jk.v11i2.227).
} 


\section{HASIL DAN DISKUSI PEMBAHASAN}

Ekspresi Wajah Orang-orang di Akhirat

Di dalam ayat-ayat agung Al-Qur'an ada dua jenis yang menunjukkan ekspresi wajah, yaitu ekspresi emosi positif dan emosi negatif yang diungkapkan oleh orang-orang di akhirat termasuk orang-orang yang celaka dan orang-orang yang bahagia seperti yang dijelaskan dan diuraikan dalam artikel ini. Ekspresi wajah adalah untuk mengungkapkan bagaimana tanda-tanda nonverbal memiliki dampak pada diri mereka sendiri dalam membentuk karakter dan mengimplementasikan interaksi dengan sukses diantara mereka $^{12}$. Emosi Positif; jenis ini mengekspresikan emosi positif dari orang-orang bahagia di akhirat. Seperti yang dijelaskan dalam ekspresi wajah orang-orang bahagia di dalam surah Al-Qiyamah ayat 22-23 "wujunbun yaomaizin naadbirob ila Robbiha naazhirob”; "yaitu di hari kiamat wajah orang-orang beriman tampak bahagia dan berseri melihat wajah Tuhan mereka”. Menurut pandangan Peirce dalam Dewey bahwa dalam ucapan dan gerakan tubuh seperti ekspresi wajah memiliki makna emotif dalam teori fakta tentang tanda-tanda dan linguistik ${ }^{13}$. Dalam jenis ekspresi wajah ini, lima bentuk makna dan emosi positif dalam kaitannya dengan orang-orang bahagia di akhirat yang akan dibahas dan dianalisis.

Pertama; Ekspresi Wajah putih berseri. Wajah putih berseri diungkapkan dalam AlQur'an dengan merujuk pada surah Al-Imran ayat 106-107; “yaoma tabyhaddu wujuub wa taswaddu wujuub”: "Pada hari itu (hari kiamat) ada ekspresi muka yang putih berseri dan ada pula muka yang hitam muram”. Dan orang yang hitam mukanya, Allah berfirman kepada mereka, mengapa kalian tidak beriman, maka sekarang ini rasakanlah azab yang disebabkan dengan perbuatan mu yang tidak mau beriman. "Wa-ammalladriina-abyadh-dhat wujuububum fafi rabmatillahi hum fiihaa khaaliduun". "Sementara orang-orang memiliki ekspresi muka putih berseri, mereka selalu dalam naungan Tuhan yang maha pengasih dan mereka hidup selamanya dalam kebahagiaan" ${ }^{\prime 14}$. Dalam ayat-ayat agung ini, Allah menerangi dan memberikan petunjuk jalan keselamatan bagi para hamba-Nya; mereka yang mengikuti jalan ini akan diberikan ganjaran pada hari kebangkitan dan mereka yang meninggalkan jalan

\footnotetext{
${ }^{12}$ Hassan, Azhar.,Abdulhussain, Maali., "A Study of Non- Verbal Codes in August Strindberg's The Stronger, Stylistic Study", Journal of Kerbala University, Vol. 14 No. 3 (2018), 10-15. (https://kj.uokerbala.edu.iq/article_157602.html).

${ }^{13}$ Dewey, John., "Peirce's Theory of Linguistic Signs, Thought, and Meaning". The Journal of Philosophy, Vol. 43 No. 4 (1946), 85-95. (10.2307/2019493).

${ }^{14} \mathrm{Al}$-Mukhtasor, Al-Mukhtasor fi Tafsiiril Qur'anil Karïm/Tashnip: Jama'atin min Ulama' it Tafsiir/Nukhbah minal ulama', Thob'ah 4, (Riyadh: Al-Markaz Liddirosaatil Qur'aniyyah, 1439 H), Bab 3, Al-Imran: 106-107.
} 
keimanan akan diazab. Oleh karena itu, yang pertama akan muncul dengan wajah putih berseri dan yang terakhir akan diangkat dengan keadaan wajah hitam dan gelap pada hari kebangkitan. Jenis orang-orang yang berwajah putih berseri dan hitam gelap, dapat mencerminkan pikiran, keyakinan, dan perbuatan mereka. Dengan demikian, wajah putih berseri orang-orang beriman dianggap sebagai tanda semiotik kebahagiaan bagi mereka yang memiliki kepercayaan dan keimanan yang kuat kepada Allah. Sedangkan wajah hitam dan gelap mencerminkan tanda orang-orang kafir yang akan menderita dan disiksa oleh Allah karena perbuatan buruk mereka ${ }^{15}$.

Kedua; Ekspresi Wajah Cemerlang. Mencerminkan tanda wajah orang-orang beriman yang sedang menunggu berhadapan dengan wajah Allah. Dalam contoh kedua ini digambarkan didalam ayat agung-Nya; "wujuubun yaomaizin naadbirob ila Robbiha naaziroh”; “Ekspresi wajah orang-orang mu'min pada hari itu putih berseri”- Karena kenikmatan memandang wajah Tuhan mereka" ${ }^{\text {}}$. Ayat-ayat ini menjelaskan keadaan orang-orang yang beriman dan yang tidak beriman pada hari kebangkitan yang masing-masing melakukan perbuatan baik dan jahat. Tanda ekspresi wajah orang yang memiliki keimanan ditunjukkan dalam ayat-ayat ini dengan menggunakan bentuk partisip dalam kata نَاضِرَةٌ “Naadhirob” di dalam surah Al-Qiyamah ayat 22 ini yang berkonotasi ekspresi wajah dalam keadaan senang disertai dengan kemakmuran, kesejahteraan, kemegahan dan keindahan. Ayat 23 ini menggambarkan tanda semiotik wajah orang-orang beriman yang mencari kemurnian esensi zat Allah dengan intuisi batin. Tanda-tanda wajah bahagia seperti itu sedang menunggu hadiah langsung dari Allah zat wajibul maulana yang akan diberikan oleh Allah kepada hamba-Nya yang ikhlas dan berilmu didalam hidup, orang-orang ini akan terserap dalam esensi kesempurnaan dan keindahan Tuhan yang Absolut.

Ketiga; Ekspresi Wajah Cerah dan Berkilau. Dalam jenis ekspresi wajah ini disebutkan dalam ayat agung Al-Qur'an tentang perbuatan baik orang-orang beriman yang menunggu kebahagiaan mereka di hari kebangkitan seperti yang ditunjukkan dalam ayat agung ini,; "wujuubun yaomaiz̨in musfiroh" " Ekspresi wajah orang-orang yang beriman pada hari kiamat putih berseri"' ${ }^{\prime 17}$. Dalam ayat ini, orang-orang beriman digambarkan memiliki

${ }^{15}$ Al-Qurtubi, A. "Al-Jamiłal-ahkam al-Qran”, (Cairo: Dar alkutoob almasreea, Vol.4, 1967), 166.

${ }^{16} \mathrm{Al}$-Mukhtasor, Al-Mukhtasor fi Tafsiiril Qur'anil Karïm/Tashnip: Jama'atin min Ulama' it Tafsiir/Nukhbah minal ulama', Thob'ab 4, (Riyadh: Al-Markaz Liddirosaatil Qur'aniyyah, 1439 H), Bab 75, Al-Qiyamah: 22-23.

${ }^{17}$ Al-Mukhtasor, Al-Mukbtasor fi Tafsiiril Qur'anil Karïm/Tashnip: Jama'atin min Ulama' it Tafsiir/Nukbbah minal ulama' Thob'ab 4, (Riyadh: Al-Markaz Liddirosaatil Qur'aniyyah, 1439 H), Bab 80, Abasa': 38. 


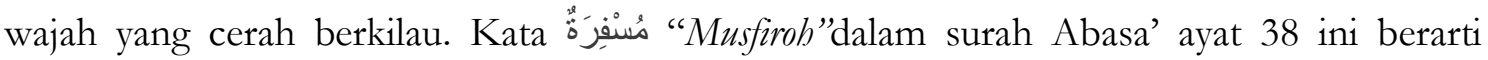
"Ekspresi wajah cerah berkilauan" dan ini menunjukkan tanda semiotik dari ekspresi wajah bersinar di pagi hari setelah malam gelap. Tanda wajah orang yang memiliki keimanan mencerminkan diri batiniah baik secara fisik maupun spiritual. Tanda semiotik dari ekspresi wajah-wajah ini menunjukkan bahwa orang-orang itu adalah orang-orang benar selama hidup mereka di dunia ini.

Makna semiotik keempat; Ekspresi Dengan Wajah Tersenyum. Dalam jenis ekspresi wajah ini menggambarkan orang-orang yang bahagia dan tersenyum di akhirat seperti yang disebutkan dalam ayat agung-Nya; “doohikatun mustabsyirob”; ضَاحِكَة "Ekspresi Wajah Tersenyum dan Gembira", karena mendengar kabar baik dari surga Firdaus karena memiliki keyakinan yang tinggi kepada Tuhan selama hidup di dunia" ${ }^{18}$. Ekspresi wajah tersenyum pada orang-orang yang memiliki keimanan, akan muncul dengan emosi kebahagiaan dan kesenangan yang mereka rasakan dan miliki. Dengan demikian orangorang beriman layak memiliki wajah tersenyum dan gembira ria di hari kebangkitan nanti ${ }^{19}$. Bentuk makna semiotik kelima; Ekspresi Wajah Ceria.Tipe terakhir ini dari orang-orang bahagia di akhirat mengungkapkan perasaan gembira, ini ditunjukkan dalam ungkapan ayat agung-Nya: "wujuubun yaomaizin naa'imab” Semua ekspresi wajah orang-orang beriman pada hari kiamat putih berseri." ${ }^{20}$. Ayat ini menggambarkan ekspresi wajah-wajah orang yang beriman dengan keadaan sukacita karena perbuatan baik mereka dan karena mereka ini akna mendapatkan kenikmatan surgawi. Perasaan gembira ini mencerminkan rahmat Allah dan hadiah bagi mereka yang takut kepada Allah dan mematuhi perintah-Nya dalam kehidupan duniawi. Dalam kata نَاعَبٌْ “Naa i'mab” di surah Al-Ghaasiyah ayat 8 ini berarti ekspresi wajah orang-orang yang mendapatkan kenikmatan, kesenangan, kenyamanan yaitu orang-orang beriman yang merasakan kenyamanan di akhirat kelak. Dengan demikian tanda kebahagiaan di wajah-wajah ini sebagai hasil dari perjuangan keras mereka di dunia untuk menahan perbuatan buruk. Oleh karena itu mereka layak mendapatkan hadiah dari Allah karena perbuatan baik mereka. Ekspresi Dengan Wajah Emosi. Jenis ekspresi wajah ini

\footnotetext{
${ }^{18} \mathrm{Al}$-Mukhtasor, Al-Mukhtasor fi Tafsiiril Qur'anil Karïm/Tashnip: Jama'atin min Ulama' it Tafsiir/Nukbbah minal ulama', Thob'ah 4, (Riyadh: Al-Markaz Liddirosaatil Qur'aniyyah, 1439 H), Bab 80, Abasa': 39.

${ }^{19} \mathrm{Al}$-Alusi, M., Spirit of meanings in the interpretation of the Holy Qur'an and the seven vescico. Dar revival of Arab heritage (Beirut: Vol. 29, 1994), 144.

${ }^{20}$ Al-Mukhtasor, Al-Mukhtasor fi Tafsiiril Qur'anil Karïm/Tashnip: Jama'atin min Ulama' it Tafsiir/Nukhbah minal ulama' Thob'ah 4, (Riyadh: Al-Markaz Liddirosaatil Qur'aniyyah, 1439 H), Bab 88; Al-Ghaasiyah: 8.
} 
mengungkapkan emosi negatif orang-orang celaka di alam akhirat. Ekspresi Wajah Emosi Negatif ini ditemukan dalam ayat-ayat Al-Qur'an dengan merujuk kepada orang-orang kafir (buta dari kebenaran) yang kehilangan kepercayaan kepada Allah dan neraka menjadi tempat tinggal mereka. Ekspresi Perasaan negatif ini diilustrasikan dan dibahas dalam subbagian berikut; Ekspresi Dengan Wajah Hitam. Diungkapkan dalam ayat ini; "Wayaumal-qiyaamati tarallazïna kazabu alallabi wujuububum muswaddab". "Dan pada hari kiamat kamu akan mengetahui ekspresi wajah orang-orang yang telah berdusta kepada Allah, maka ekspresi wajah mereka berubah menjadi gelap dan hitam. Bukankah di neraka jahannam itu telah disediakan tempat bagi orang-orang yang membanggakan dirinya" ${ }^{21}$ ? Dalam ayat ini adalah deskripsi bagi ekspresi wajah orang-orang kafir yang berbohong. Pada hari kebangkitan wajah orang yang tidak percaya kepada ajaran-ajaran Allah, akan digelapkan atau dihitamkan karena perbuatan mereka yang buruk yang pernah dilakukan di dunia fana. Ayat ini adalah tanda semiotik ketidakbahagiaan dan hukuman berat dari Allah yang pantas mereka terima karena mereka yang tidak taat dan tidak percaya dan mengklaim bahwa para malaikat dan sejenisnya adalah keturunan Allah ${ }^{22}$.

Ekspresi Dengan Wajah Terhina; secara kiasan diekspresikan dalam ayat berikut; "Wallazina kasabus-sayyiaati-jazaa'u sayyiatin bimitsliba wa tarhaqubum dzillah, maa labum minallabi min aasim, ka'annama ugsiyat wujuububum qito'am minal laili muqlima". "Dan orangorang yang mengerjakan kejahatan akan memperoleh ganjaran yang setimpal dan ekspresi wajah mereka ditutupi kehinaan dan wajah mereka itu gelap seperti potongan malam yang gelap gulita karena dosa yang mereka perbuat selama di dunia"'23.Referensi ekspresi wajah terhina dalam ayat ini menunjukkan orang-orang tidak percaya dan melakukan perbuatan jahat dan dosa, karena itu mereka akan mendapatkan hukuman yang terkait dengan tindakan yang dilakukan berdasarkan akal dan rasio mereka. Karena Allah akan mengazab semua manusia sesuai dengan hasil perbuatan akal dan hati mereka. Ayat ini menyimpulkan bahwa tidak ada cara untuk melarikan diri dari hukuman Allah. Ini ditunjukkan pada ekspresi wajah-wajah terhina mereka yang mencerminkan siksaan abadi dalam api neraka. Demikian pula ekspresi “wajah gelap”juga dijelaskan dengan mengacu pada ayat berikut:

${ }^{21}$ Al-Mukhtasor, Al-Mukbtasor fi Tafsiiril Qur'anil Kariim/Tashnip: Jama'atin min Ulama' it Tafsiir/Nukhbah minal ulama' Thob'ab 4, (Riyadh: Al-Markaz Liddirosaatil Qur'aniyyah, 1439 H), Bab 39 ; Az-Zumar: 60.

${ }^{22} \mathrm{Al}$-Alusi, M.Sprint of meanimgs in the interpretation of the Hob Qur'an and theseven vescico. Dar revival of Arab heritage, (Beirut: Vol. 24 1994), 19. Lihat juga Al-Qurtubi, A, Al-Jami al-Ahkam al-Qran, (Cairo: Daralkutoob almasreea. Vol.15, 1967), 274. ${ }^{23}$ Al-Mukhtasor, Al-Mukhtasor fi Tafsiiril Qur'anil Kariim/Tashnip: Jama'atin min Ulama' it Tafsiir/Nukbbah minal ulama' Thob'ah 4, (Riyadh: Al-Markaz Liddirosaatil Qur'aniyyah, 1439 H), Bab 10, Yunus: 27. 
"wujuubun yaomaizin alaiha ghobaroh-tarhquba qotaroh" "Dan banyak (pula) ekspresi wajah pada hari itu tertutup debu. Dan ditutup lagi oleh kegelapan (mereka ditimpa kehinaan dan kesusahan) ${ }^{\prime 24}$.Ekspresi pada tanda-tanda diwajah mereka memiliki makna dan simbol untuk diinterpretasikan secara verbal. Pikiran tidak harus terhubung dengan otak sehingga tidak ada pemikiran tanpa tanda atau kata-kata. Disini kita harus memberi "tanda" arti yang sangat luas, mengakui bahwa "Tanda" yang terhubung harus memiliki "quasi-mind", selanjutnya dapat dinyatakan bahwa tidak ada tanda atau kata-kata yang terisolasi. Selain itu, tanda-tanda membutuhkan setidaknya dua pikiran-kuasi; quasi-utterer dan quasi-interpreter dan meskipun keduanya bersatu (yaitu, satu pikiran) dalam tanda itu sendiri, mereka harus berbeda. Mereka didalam tanda, bisa dikatakan "dilas". Dengan demikian, ini bukan hanya fakta psikologis manusia, tetapi suatu keharusan logika bahwa setiap evolusi pemikiran logis harus dialogis ${ }^{25}$. Tanda memiliki dua fungsi diantaranya yaitu "tanda" bisa menjadi subjek bilamana memberikan pesan kepada para pembacanya. Sisi lainnya "tanda" juga bisa berfungsi sebagai objek bacaan bilamana dipahami isi pesannya oleh pembaca. Dengan demikian tanda memiliki peran ganda dalam kegiatan dialogi yaitu bisa menjadi objek dan juga bisa menjadi subjek ${ }^{26}$. Pada saat seorang pembaca membaca tanda, itu berarti dia sudah menafsirkan tanda bahasa. Pentingnya ilmu tanda dan simbol telah diakui oleh Al-Qur'an dan oleh para peneliti secara luas, tetapi hanya segelintir peneliti yang mengembangkan teori dan penelitian berdasarkan semiotika (doktrin tanda) ${ }^{27}$.

Dalam konteks ini istilah bahasa Arab kata "Ghobaroh dan Qomarob" dalam ayat 40 dan 41 disurah Abasa' ini berarti "Ekspresi wajah yang berada didalam debu yang kotor" yang akan menutupi wajah mereka, yang didefinisikan dalam kata "Qomaroh" yaitu, "Ekspresi wajah yang tertutupi oleh asap rokok yang hitam pekat"28. Secara alegoris istilah "Qomarob” dalam ayat ini didefinisikan "sebagai ekspresi wajah yang gelap yang disertai kehinaan dan kesusahan”. Demikian juga seperti yang ditafsirkan oleh Al-Qurtubi ${ }^{29}$ ketika

\footnotetext{
${ }^{24}$ Al-Mukhtasor, Al-Mukbtasor fi Tafsiiril Qur'anil Karïm/Tashnip: Jama'atin min Ulama' it Tafsiir/Nukhbah minal ulama' Thob'ah 4, (Riyadh: Al-Markaz Liddirosaatil Qur'aniyyah, 1439 H),Bab 80, Abasa': 40-41.

${ }^{25}$ Pierce, Sanders Charles., "Rolegomena To an Apology For Pragmaticism", The Monist, Vol. XVI No. 4 (1906), 492-546.

${ }^{26}$ Chaer, H., dkk., Hermeneutika Al-Qur'an Suroh Al-Isro' Ayat 1: Sebuah Tinjauan Kosmologi. PALAPA, Vol. 7 No. 1 (2019), 66-98.

${ }^{27}$ Mick, David Glen. "Consumer Research and Semiotics: Exploring the Morphology of Signs, Symbols, and Significance", Journal of Consumer Research, Vol. 13 No. 2, (1986), 196-123. (10.1086/209060).

${ }^{28}$ Arberry, Arthur., "The Koran Interpreted”, Middle East Forum, Vol. 12 (1955), 24.

${ }^{29} \mathrm{Al}-\mathrm{Qurtubi}, \mathrm{A}, \mathrm{Al}-J a m i$ al-Ahkam al-Qran, (Cairo: Daralkutoob almasreea. Vol.15, 1967), 222.
} 
dia mengatakan dalam ayat 41 ini yaitu "aib dan kegelapan/ditimpa kesusahan dan kehinaan". Jadi dimungkinkan bahwa kata "kegelapan" untuk mengatakan ekspresi wajah orang-orang kafir yang bernoda dan berdebu (yaitu noda debu yang menutupi wajah dan menyebar kesemua wajah orang-orang kafir pada hari kebangkitan. Seorang penafsir adalah apa yang dihasilkan dari proses penafsiran adalah salah satu jenis kegiatan yang berada dibawah ranah semiotik. Peirce dalam Arisbe (1868) berpendapat bahwa logika adalah studi formal tentang tanda-tanda dalam arti luas, tidak hanya tanda-tanda yang artifisial, linguistik, atau simbolis, tetapi juga tanda-tanda yang mirip atau bersifat indeksik seperti reaksi didalam ekspresi wajah ${ }^{30}$.

Ekpresi wajah yang muram; juga disebutkan dalam ayat Al-Qur'an berikut “mujuubun yaomaiæin baasirob”: "Ekspresi wajah orang-orang kafir pada saat itu (hari kiamat) menjadi hitam dan muram"31. Ayat ini menggambarkan orang-orang kafir yang menuruti kesenangan duniawi dan mengabaikan alam keabadian akhirat; ini yang kemudian membuat mereka muncul dengan ekspresi wajah suram, muram, cemberut, gelap dan sedih di hari kiamat. Bentuk kata Arab "baasiroh" dalam ayat 24 surah Al-Qiyamah ini memiliki makna "suram, muram" yang menunjukkan "mentah, tidak pantas" yang menunjukkan buah yang mentah dan terhubung ke penampilan ekspresi dengan wajah yang suram. Akibatnya ketika orang-orang kafir tahu tentang hasil perbuatan mereka, ekspresi wajah-wajah itu berubah sangat cemberut dan hitam. Dengan demikian ekspresiwajah-wajah ini jelas menggambarkan keadaan menyedihkan dari kesengsaraan dan kengerian yang dialami melalui ekspresi wajah dan hati mereka karena mengetahui bahwa siksaan dan bencana akan terjadi dan menghancurkan mereka.

Ekspresi dengan wajah terhina. Mari kita perhatikan kalimat ayat berikut ini” wujuubun yaomaizin khosyiah” "wajah-wajah orang kafir pada hari kiamat tunduk terhina karena disebabkan oleh dosa-dosa kekafiran mereka kepada Allah"32. Dalam ayat agung ini, Allah yang Maha Kuasa memperingatkan orang-orang kafir dengan berbicara kepada Nabi Muhammad tentang ketakutan dan kengerian hari kebangkitan. Ayat ini menggunakan kata jamak yaitu “wujuub” yang menunjukkan banyak sekali dengan ekspresi wajah ekstrim dan

\footnotetext{
${ }^{30}$ Arisbe, "Questions Concerning Certain Faculties Claimed for Man", Eprint, Journal of Speculative Philosophy, Vol. 2, (1868), 103-114.

${ }^{31}$ Al-Mukhtasor, Al-Mukhtasor fi Tafsiiril Qur'anil Karïm/Tashnip: Jama'atin min Ulama' it Tafsiir/Nukbbab minal ulama' Thob'ah 4, (Riyadh: Al-Markaz Liddirosaatil Qur'aniyyah, 1439 H),Bab 75, Al-Qiyamah: 24.

${ }^{32} \mathrm{Al}-\mathrm{Mukhtasor,}$ Al-Mukhtasor fi Tafsiiril Qur'anil Karïm/Tashnip: Jama'atin min Ulama' it Tafsiir/Nukhbah minal ulama' Thob'ah 4, (Riyadh: Al-Markaz Liddirosaatil Qur'aniyyah, 1439 H), Bab 88, Al-Ghaasyiah:2.
} 
perasaan yang menakutkan. Sebenarnya dalam ilmu tafsir kata "Khosyi"ah" ini dianggap sebagai tanda bagi ekspresi wajah orang-orang beriman yang tunduk dan takut akan sesuatu dan mematuhi perintah Allah, tetapi dalam hal ini, ayat ini menunjukkan ekspresi dengan wajah ketakutan ekstrim yang menutupi wajah orang-orang kafir pada hari itu karena hukuman yang mengerikan. Dengan demikian ekspresi wajah orang-orang kafir merupakan indikasi untuk suasana hati spiritual mereka yang tampaknya menunjukkan penghinaan total dan mengerikan. Ekspresi dengan wajah terhina, juga ditekankan dalam ayat; "Wallazina kasabus-sayyiaati-jaza'u sayyiatin bimitsliba wa tarhaqubum drillab". "Dan orang-orang yang mengerjakan kejahatan (mendapat) balasan yang setimpal dan ekspresi wajah mereka ditutupi oleh kehinaan"33. Dalam ayat ini, adalah rujukan pada jenis hukuman orang-orang kafir yang pantas diterima karena kejahatan dan perbuatan buruk mereka yang dilakukan dalam kehidupan duniawi. Dalam ungkapan Al-Qur'an di ayat ini yaitu "Tarhaqubum Džillah”, yaitu "Ekspresi wajah yang ditutupi kehinaan” menunjukkan bahwa orang-orang kafir semacam itu akan dihadapkan pada hukuman yang pedih dimana tidak ada halangan dan pencegahan dari siksaan Allah. Ekspresi wajah mereka ditutupi dengan kegelapan dan kehinaan pada saat itu mereka membuang bayangan atau cermin wajah mereka dimalam hari. Ini adalah rujukan dan tanda bagi orang-orang yang akan bergabung didalam api neraka yang menyala tanpa henti. Menurut Peirce dalam Pietarinen bahwa memaknai dan menerjemahkan kata, tanda dan simbol ketuhanan seperti didalam ayat "Tarbaqubum Dzillah" ini diadopsi oleh para pemikir teologi berasal dari teori tanda Charles Sanders Peirce dan logika filsafat pragmatisnya. Hal ini merupakan asumsi dasar bahwa pemahaman komunikasi melalui semiotika merupakan pandangan yang intensif dan bijaksana antar lintas disiplin ilmu ${ }^{34}$.

\section{Ekspresi Wajah Orang-orang di Dunia Sekarang}

Dalam jenis ekspresi wajah ini, ada berbagai bentuk dan tanda yang menunjukkan perbedaan makna dan emosi positif dan negatif yang akan didiskusikan dan dianalisis dalam artikel ini. Ekspresi Dengan Wajah Kebencian. Beberapa ekspresi wajah dalam Al-Qur'an adalah wajah orang-orang yang membenci hak dan kewajiban dalam kehidupan didunia

${ }^{33} \mathrm{Al}$-Mukhtasor, Al-Mukhtasor fi Tafsiiril Qur'anil Kariim/Tashnip: Jama'atin min Ulama' it Tafsiir/Nukhbah minal ulama' Thob'ah 4, (Riyadh: Al-Markaz Liddirosaatil Qur'aniyyah, 1439 H), Bab 10, Yunus: 27.

${ }^{34}$ Pietarinen, Ahti-Veikko. "Grice in the wake of Peirce",Journal Pragmatics of Condition, Vo. 12 No. 2 (2004), 295-315. 
sekarang. Seperti yang akan dibahas didalam ayat ini; "Wa-idqaa tutla alaibim aayaatunaa bayyinaatin ta'rifu fii wujumbilladziina kafarul munkara. Yakaaduun yasthunna". "Dan apabila dibacakan dihadapan mereka ayat-ayat Kami yang terang, niscaya kamu melihat tanda-tanda keingkaran pada ekspresi wajah orang-orang yang kafir itu”35. Ayat ini menggambarkan ketegaran para penyembah berhala terhadap ayat-ayat Allah. Dalam ayat ini tampaknya orang-orang kafir tidak mengetahui dengan ancaman Allah, berbeda dengan logika ayat-ayat Al-Qur'an yang dilapazkan oleh orang-orang yang beriman. Dan karena mereka kafir terhadap kebenaran yang dibawa oleh Allah melalui rasul-Nya kepada mereka, tanda-tanda ekspresi cemberut diwajah mereka dengan perasaan benci dan menolak kebenaran ayat-ayat Allah. Tanda-tanda semacam ini menunjukkan bahwa mereka bersiap untuk mengambil tindakan dimasa yang akan datang dan ini ditunjukkan dalam lanjutan kalimat ayat ini melalui penggunaan frase bahasa Arab yaitu كَادُونَ يَنْطُونَ 'Yakaaduuna Yasthuuna"yang berarti "hampir mereka siap untuk menyerang dengan kekerasan"atau mengangkat tangan untuk menyerang pihak lawan". Dalam hal ini, ekspresi wajah mereka meramalkan kepastian untuk melakukan tindakan kekerasan dimasa-masa yang akan datang. Semiologi mengkaji studi bahasa dan fungsinya sebagai bagian dari penggunaan tanda-tanda yang terintegrasi dalam komunikasi manusia. Sebagai contoh pendekatan tekstualisasi. Disini bahasa melengkapi dan dilengkapi dengan tanda-tanda non-linguistik dalam interelasi yang sangat kompleks. Tekstualisasi dipilih untuk studi karena dunia modern semakin bergantung pada kompetensi sosial yang diselenggarakan melalui teks. Teks (tertulis, dicetak, diukir dan lain-lain). Tekstualisasi semiologi jauh melampaui pemahaman membaca dan menulis. Implikasi dari pendekatan terhadap semiologi memiliki konsekuensi penting bagi definisi kita tentang tanda lingusitik itu sendiri ${ }^{36}$. Oleh karena itu ayat ini menggambarkan perilaku agresif mereka terhadap orang-orang yang membacakan ayat-ayat suci kepada mereka dan ini disebabkan oleh kefanikan mereka dan keras kepala. Karena itu Allah menghukum orang-orang kafir dengan sangat parah dengan memasukkan mereka kedalam api yang menyala-nyala ${ }^{37}$.

\footnotetext{
${ }^{35} \mathrm{Al}$-Mukhtasor, Al-Mukbtasor fi Tafsiiril Qur'anil Karïm/Tashnip: Jama'atin min Ulama' it Tafsiir/Nukbbah minal ulama' Thob'ah 4, (Riyadh: Al-Markaz Liddirosaatil Qur'aniyyah, 1439 H),Bab 22, Al-Hajj: 72.

${ }^{36}$ Harris, Roy., “The Semiology of Textualization”,Language Science, Vol. 6 No. 2 (1984), 271-286.

${ }^{37}$ Al-Alusi, M. Spirit of meanings in the interpretation of the Hoby Qur'an and theseven vescico. Dar revival of Arab heritage, (Beirut: Vol. 24 1994), 19. Lihat juga Al-Qurtubi, A, Al-Jami al-Ahkam al-Qran, (Cairo: Daralkutoob almasreea. Vol.15, 1967), 95.
} 
Ekspresi Dengan Wajah Kesedihan. Seperti dalam contoh ayat agung Al-Qur'an berikut ini; "wa idzaa bussyiro abadubum bil untsa zolla wajbubu muswaddan wabuwa kazhiim" "Dan apabila mereka dikabari dengan lahirnya anak perempuan mereka, maka ekspresi wajah mereka menjadi hitam kemerahan dan dia sangat marah dan bersedih hati dengan memiliki anak perempuan" "yatawaaro minal qoumi min sun'i maa bussyiro bibi". "Dia merasa malu dan bersembunyi dari masyarakatnya karena mendengar kabar buruk dengan kelahiran anak perempuan mereka”,38. Ayat-ayat ini merujuk pada kebiasaan orang-orang kafir jahiliyah Arab yang mengerikan, ketika mereka diberitahu memiliki anak perempuan sebagai amanah dari Allah maka ekspresi wajah mereka menjadi gelap dan hitam dan penuh amarah karena mendapatkan seorang anak perempuan dianggap sebagai aib dan kehinaan. Mereka menganggap memiliki anak perempuan sebagai hasil dari sebuah skandal yang menurut keyakinannya adalah benar dan untuk menyelamatkan diri dari keadaan yang mereka anggap hina ini, ia menghindar dari orang-orang. Karena itu mereka memutuskan untuk menguburkan ke dalam tanah anak-anak perempuan yang hidup meskipun mereka memiliki hak untuk hidup seperti anak laki-laki. Tindakan ini dikutuk oleh Islam karena Allah memberi hak untuk hidup bagi anak perempuan dan anak laki-laki untuk melanjutkan generasi manusia. Dengan demikian ayat-ayat ini memberikan pesan tentang tanda emosi batin yang rusak dan kotor dengan ekspresi wajah hitam merah yang menyatu dengan emosi kemarahan dan kebencian.

Ekspresi Dengan Wajah Malu dan Menindas. Sebagaimana dijelaskan didalam ayat ini ; 'In absantum -absantum li anfusikum, wa in asa'tum fa lahaa-fa iza jaa'a wa'dul aakbirati liyasu'u wnjunbakum". "Jika kamu berbuat baik (berarti) kamu berbuat baik bagi dirimu sendiri, dan jika kamu berbuat jahat, maka (kejahatan) itu bagi dirimu sendiri, dan apabila datang saat hukuman bagi (kejahatan) yang kedua, (kami datangkan orang-orang lain) untuk menyuramkan muka-muka kamu" ${ }^{\prime 39}$. Ayat diatas menyatakan aturan umum dan abadi bahwa semua kebaikan dan kejahatan yang kita kerjakan pada akhirnya akan kembali ke dirinya sendiri. Orang-orang kafir mengikuti jalan penindasan, pelangggaran, menghasut, dan melampaui batas kesombongan dan keunggulan diri meskipun Allah menghukum keras bagi mereka yang melakukan perbuatan buruk ini. Ketika janji Allah muncul untuk orang-

${ }^{38} \mathrm{Al}-\mathrm{Mukhtasor,}$ Al-Mukhtasor fi Tafsiiril Qur'anil Karïm/Tashnip: Jama'atin min Ulama' it Tafsiir/Nukbbab minal ulama' Thob'ah 4, (Riyadh: Al-Markaz Liddirosaatil Qur'aniyyah, 1439 H), Bab 16, An-Nahl: 58-59.

${ }^{39} \mathrm{Al}-\mathrm{Mukhtasor,}$ Al-Mukhtasor fi Tafsiiril Qur'anil Karïm/Tashnip: Jama'atin min Ulama' it Tafsiir/Nukhbah minal ulama' Thob'ab 4, (Riyadh: Al-Markaz Liddirosaatil Qur'aniyyah, 1439 H), Bab 17, Al-Israa': 7. 
orang kafir, mereka akan merasakan sakit, malapetaka dan kesedihan yang muncul diwajah mereka dalam bentuk tanda-tanda kesedihan dan keputus-asaan.

Ekspresi Dengan Wajah yang Bimbang. Seperti yang digambarkan dalam ayat ini; "afaman yamsyi mukibban ala wajhibi abdaa am man yamsyi sawiyyan ala sirootim mustaqiim" "Apakah orang yang berjalan terjungkel dengan ekspresi wajah yang bimbang itu akan memiliki lebih banyak petunjuk daripada orang yang berjalan dengan tenang dan berjalan diatas kebenaran agama"40? Dalam ayat ini ada perbandingan antara orang-orang kafir dan orang-orang beriman. Orang-orang kafir digambarkan sebagai simbol ekspresi kesombongan dan orang-orang yang sombong diibaratkan sebagai orang yang merangkak dengan tidak rata dan berjalan dengan berkelok-kelok. Hal ini jelas perumpamaan yang akurat dan signifikan tersebut tercermin dalam kehidupan dua pihak, yaitu orang-orang kafir dan orang-orang beriman. Makna yang disebutkan diatas lebih konsisten dengan makna kontekstualnya yang menggambarkan keadaan mereka yang berjalan congkak seperti diwajahnya, dan kemudian konteks berikut dibandingkan dengan mereka yang berjalan tegak. Namun demikian, keadaan ini tidak harus dibatasi pada satu kehidupan saja dalam konteks ini. Karena makna semantik dan semiotik tidak terbatas pada kehidupan akhirat. Deskripsi keadaan orang-orang kafir dan orang-orang beriman untuk mengekspresikan kehidupan akhirat maupun kehidupan di dunia saat ini.

Ekspresi Dengan Wajah Yang Dipuja dan Baik. Seperti yang dijelaskan dalam ayat ini; "sïmaahum fii wujuubibim min atsaris-sujund"; "Ekspresi di wajah mereka bersih dan suci karena bekas ibadah dan selalu bersujud kepada Allah"41. Bekas sujud yang dimaksud dalam ayat ini yaitu pada air muka mereka kelihatan keimanan dan kesucian hati mereka. Kata Arab "Siimaabum" dalam ayat ini secara harfiah berarti tanda untuk menunjukkan ekspresi wajah atau bagian tubuh lainnya. Menurut Al-Qurtubi ${ }^{42}$ itu adalah tanda pengabdian do'a pada malam hari kepada Allah yang maha kuasa. Jadi itu adalah tanda penyembahan kepada Allah. Pendapat Al-Qurtubi ini dikuatkan lagi oleh hadis Nabi; "Man Katsurat solatubu billaili. Husnu wajhubu binnabaari", yaitu "siapa yang banyak berdoa'a dan solat pada malam hari, ekspresi wajah mereka menjadi baik dan bersih disiang hari”. Dengan demikian

${ }^{40}$ Al-Mukhtasor, Al-Mukhtasor fi Tafsiiril Qur'anil Kariim/Tashnip: Jama'atin min Ulama' it Tafsiir/Nukhbah minal ulama' Thob'ah 4, (Riyadh: Al-Markaz Liddirosaatil Qur'aniyyah, 1439 H), Bab 67, Al-Mulk: 22.

${ }^{41} \mathrm{Al}$-Mukhtasor, Al-Mukhtasor fi Tafsiiril Qur'anil Kariim/Tashnip: Jama'atin min Ulama' it Tafsiir/Nukbbab minal ulama' Thob'ah 4, (Riyadh: Al-Markaz Liddirosaatil Qur'aniyyah, 1439 H),Bab 48, Al-Fath: 29.

${ }^{42} \mathrm{Al}-\mathrm{Qurtubi}, \mathrm{A}, \mathrm{Al}-J a m i$ al-Ahkam al-Qran, (Cairo: Daralkutoob almasreea. Vol.15, 1967), 293. 
kecemerlangan dan rahmat dapat terlihat di ekspresi wajah mereka karena cahaya iman dan rasa relaksasi dan ketenangan pikiran yang mereka miliki saat mereka memurnikan keimanan dengan penyembahan dan solat pada malam hari. Oleh karena itu Al-Qurtubi menyatakan bahwa itu juga menunjukkan ekspresi wajah yang putih berseri di hari kebangkitan, atau bisa juga ekspresi cahaya wajah orang-orang beriman pada saat itu.

Ekspresi Dengan Wajah Ibadah. Seperti yang gambarkan didalam ayat ini; "qod naraa taqolluba wajhika fissamaa'i" "Sesungguhnya kami (sering) melihat wajahmu menengadah dan selalu berdoa dengan mengarahkan wajahmu ke atas langit" "fawalli wajhaka syathrol masjidil haroom" "Hadapakan mukamu ke arah Masjidil Haram"43. Dalam ayat ini umat Islam diperintahkan untuk menjadikan Masjid suci di Makkah sebagai kiblat umat Islam untuk jalan dan aturan menyembah Allah. Sebelumnya orang-orang menyembah Allah ke arah Yerussalem dan kemudian arah shalat diubah ke Makkah. Perintah Allah turun kepada Nabi Muhammad ketika dia berada di Madinah untuk mengubah arah shalat dari Yerussalem ke Ka'bah. Ini sepenuhnya menunjukkan kesatuan yang Allah inginkan untuk semua manusia dibawah panji Nabi Muhammad. Perubahan arah shalat ditolak oleh orang-orang Yahudi dan Kristen meskipun mereka tahu bahwa perubahan ini adalah tanda kebenaran para Nabi sebagaimana disebutkan didalam kitab suci mereka tentang deskripsi Nabi Muhammad dan bangsanya. Namun Allah tidak lalai atas reaksi mereka terhadap Nabi dan akan menghukum mereka di dunia sekarang dan di akhirat $^{44}$. Simbolisme dan ikonografi telah digunakan oleh semua agama di dunia. Sejak abad ke-20 beberapa ilmuan telah menekankan karakter simbolik agama daripada upaya untuk menghadirkan agama secara rasional. Aspek simbolis agama bahkan dianggap oleh beberapa peneliti psikologi dan mitologi sebagai ciri utama ekspresi keagamaan ${ }^{45}$.

\section{KESIMPULAN}

Komunikasi manusia tidak hanya mencakup kata-kata yang diucapkan tetapi juga mencakup ekspresi wajah sebagai sarana yang sangat efektif untuk mengekspresikan emosi dan pikiran. Dengan demikian analisis semiotika ayat-ayat Al-Qur'an diatas yang penulis

\footnotetext{
${ }^{43} \mathrm{Al}$-Mukhtasor, Al-Mukbtasor fi Tafsiiril Qur'anil Kariim/Tashnip: Jama'atin min Ulama' it Tafsiir/Nukhbah minal ulama' Thob'ah 4, (Riyadh: Al-Markaz Liddirosaatil Qur'aniyyah, 1439 H), Bab 2, Al-Baqarah: 144.

${ }^{44} \mathrm{Al}$-Azzawi, Shifaa Mohammed. et.al "A Semiotic Analysis of the Body Language With Reference to the Facial Expressions in Selected Quranic Verses", IRA International Journal of Education and Multidisciplinary Studies, Vol. 3 No. 2 (2016), 8. (http://dx.doi.org/10.21013/jems.v3.n2.p8).

${ }^{45}$ Whiting, Robert.,Religions for Today,(London: Stanley Thomes, 1991), viii.
} 
teliti adalah untuk menjadikan lebih jelas dan mudah dipahami apa yang dituturkan Allah sebagai sarana komunikasi dialog antara Tuhan dan manusia melalui analisis semiotika. Juga sebagai pengayaan kerangka teori kepustakaan Al-Qur'an dibidang semiotika sehingga dapat menjelaskan interpretant yang masih samar yang memungkinkan terwujudnya "Tanda" baru yang menghasilkan satu rangkaian analisis semiosis yang bisa melahirkan interpretant-interpretant baru yang terus menerus dan saling terkait sehingga ilmu bahasa dan sastra yang ada di dalam ayat-ayat Al-Qur'an yang masih tersembunyi bisa terurai dan dijelaskan secara ilmiah. Walaupun pada akhirnya hasil penafsiran bisa berbeda tergantung dari persepsi dan latarbelakang keilmuan penafsir dalam menginterpretasikan sebuah tanda, kata dan kalimat ayat-ayat Al-Qur'an. Namun yang menjadi ukuran disini bukanlah untuk mencari salah dan benar karena kebenaran itu memang relatif. Tetapi untuk memperoleh interpretasi yang lebih tepat, setidaknya menurut interpretasi penulis.

\section{DAFTAR PUSTAKA}

Abdullah, A., et. al., "The Semiotic Studies of the Holy Qur'an”, QURANICA-International Journal Of Quranic Research, Vol. 8 No. 1 (2016), 91-108. (https://doi.org/10.22452/quranica.vol8no1.6.)

Al-Alusi, M.,Spirit of meanings in the interpretation of the Holy Qur'an and the seven vescico. Dar revival of Arab heritage, (Beirut: Vol. 24 1994), 19.

Al-Alusi, M.Spirit of meanings in the interpretation of the Holy Qur'an and the seven vescico. Dar revival of Arab heritage, (Beirut: Vol. 24 1994), 19.

Al-Alusi, M., Spirit of meanings in the interpretation of the Holy Qur'an and the seven vescico. Dar revival of Arab heritage (Beirut: Vol. 29, 1994), 144.

Al-Azzawi, Shifaa Mohammed. et.al "A Semiotic Analysis of the Body Language With Reference to the Facial Expressions in Selected Quranic Verses", IRA International Journal of Education and Multidisciplinary Studies, Vol. 3 No. 2 (2016), 8. (http://dx.doi.org/10.21013/jems.v3.n2.p8).

Al-Mukhtasor, Al-Mukhtasor fi Tafsiiril Qur'anil Kariim/Tashnip: Jama'atin min Ulama' it Tafsiir/Nukhbah minal ulama' Thob'ah 4, (Riyadh: Al-Markaz Liddirosaatil

Qur'aniyyah, 1439 H). Bab 2, Al-Baqarah: 144, Bab 3, Al-Imran: 106-107, Bab 10, Yunus: 27, Bab 16, An-Nahl: 58-59, Bab 17, Al-Israa': 7, Bab 22, Al-Hajj: 72, Bab 39 ; Az-Zumar: 60, Bab 48, Al-Fath: 29, Bab 67, Al-Mulk: $\quad$ 22, Bab 75, Al-Qiyamah: 22,23,24, Bab 80, Abasa': 38, 39, 40,41, Bab 88, Al- Ghaasyiah: 2 dan 8.

Al-Qurtubi, A, Al-Jami al-Ahkam al-Qran, (Cairo: Daralkutoob almasreea. Vol. 15, 1967). Arberry, Arthur., “The Koran Interpreted”, Middle East Forum, Vol. 12 (1955), 24. 
Arisbe, "Questions Concerning Certain Faculties Claimed for Man", Eprint, Journal of Speculative Philosophy, Vol. 2, (1868), 103-114.

Chaer, H., dkk. 'Hermeneutika Al-Qur'an Suroh Al-Isro' Ayat 1: Sebuah Tinjauan $\begin{array}{lllll}\text { Kosmologi”. PALAPA, Vol. } & 7 & \text { No. } & 1 & \text { (2019), }\end{array}$ https://doi.org/10.36088/palapa.v7i1.182.

Dewey, John., "Peirce's Theory of Linguistic Signs, Thought, and Meaning". The Journal of Philosophy, Vol. 43 No. 4 (1946), 85-95. (10.2307/2019493).

Eisenberg, A. M. \& R. R. Smith, Nonverbal Communication, (New York: The BobbsMerrill Company, Inc., 1971), 213.

Ekman, P., What the facereveals (2nd edition): Basic and applied studies of spontaneous Expression using the Facial Action Coding System (FACS), (2005), 388-392.

Harris, Roy., “The Semiology of Textualization”, Language Science, Vol. 6 No. 2 (1984), 271 286.

Hassan, Azhar., Abdulhussain, Maali., "A Study of Non- Verbal Codes in August Strindberg's The Stronger, Stylistic Study”, Journal of Kerbala University, Vol. 14 No. 3 (2018), 10-15. (https://kj.uokerbala.edu.iq/article_157602.html).

Izard, C., The face of Emotion, (New York: Appleton-Century-Crofts, (1971), 119.

Kerajaan Saudi Arabia, Al-Qur'an, (Riyad: Raja Fahd ibn’Abd al'Aziz Al Sa’ud, 1990).

Kurnianto, Ery Agus., "Analisis Tiga Tataran Aspek Semiotik Tzvetan Todorov Pada Cerpen "Pemintal Kegelapan" Karya Intan Paramaditha", KANDAI, Vol. 11 No 2, (2015), 206-216. (https://doi.org/10.26499/jk.v11i2.227).

Levine, D. R. \& M. B. Adelman., Beyond language: Intercultural Communication for English as a Second Language. Englewood Cliffs, (New York: Prentice-Hall, Inc., 1982), 234.

Mick, David Glen. "Consumer Research and Semiotics: Exploring the Morphology of Signs, Symbols, and Significance", Journal of Consumer Research, Vol. 13 No. 2, (1986), 196-123. (10.1086/209060).

Morris, Charles., "Charles Morris and the Behavioral Foundations of Semiotics. In: Krampen M., Oehler K., Posner R., Sebeok T.A.”, von Uexküll T. (eds),Classics of Semiotics. Topics in Contemporary Semiotics, (Boston: Springer, 1987), 23-57.

Pierce, Sanders Charles., "Rolegomena To an Apology For Pragmaticism", The Monist, Vol. XVI No. 4 (1906), 492-546.

Pierce, Sanders Charles.,State of Vermont V. Carroll B. Pierce. Supreme Court of Vermont, (Bennington, 1958), 167.

Pietarinen, Ahti-Veikko. "Grice in the wake of Peirce", Journal Pragmatics of Condition, Vo. 12 No. 2 (2004), 295-315.

Whiting, Robert.,Religions for Today, (London: Stanley Thomes, 1991), viii.

Winarsih, Suko., "Representasi Bahasa dalam Pertarungan Simbolik dan Kekuasaan". Jurnal Babasa Lingua Scientia, Vol. 5 No. 1 (2013), 11-24. (10.21274/1s.2013.5.1.11-24). 